hősök és uralkodók képmása Martin Kuthen ze Šprinsberka Kronikájában [Praha, Pavel Severin 1539]. A Kronika českát egyébként legújabban éppen szerzőnk, Petr Voit adta ki kommentárral, utószóval 2013-ban. A Severin-Biblia (1537) világ teremtésének illusztrációjáról viszont azonnal Heltai Gáspár könyvének illusztrációja jut eszünkbe: a köralakba komponált felhők, vizek között a paradicsomi jelnettel. A rendkívül gazdag, több száz fametszetű képpel szemben - a magyarországi nyomdákhoz képest - szembetünően szegény a vignetták (záródíszek) készlete, amely nálunk sokszor pótolja az igényesebb fametszeteket.

Természetesen ebben a kötetben nem a cseh reneszánsz, sőt kora reneszánsz könyvmüvészet teljességét látjuk, bizonyos témák azonban nem fordulnak elő, mint a haláltánc illusztráció sorozat (amely nálunk Brassóból ismert), vagy a több nyomdából, többféle változatban meglévő kalendáriumi hónapkép-sorozat, és hiányzik a nálunk Honterus tevékenységének köszönhetően gazdag térkép-metszetek sora is.

Szembeötlő hasonlóságokat látunk a cseh és magyarországi címlapkeretek között: az építészeti elemekből, ajtó-kerethez hasonló címlap-díszek, középen a szöveggel, kedvelt, visszatérő elemei több magyarországi nyomdának is: mindenekelőtt a brassói, szebeni de a kolozsvári nyomdának is, gyakran a cseh gyakorlathoz hasonlóan a keret aljába, vagy felső részébe komponált városcímerrel.

Minthogy cseh földön ebben a korban a fraktur és svabachi betü volt az általános, tehát az iniciálék terén szinte semmi hasonlóságot nem találni a magyarországi, túlnyomórészt antikva betűket ábrázoló díszes kezdőbetűkkel. A nyomdabetűk választéka egészen más, mint a magyarországi nyomdákban, ahol a bastarda betüt mindössze a sárvárújszigeti nyomda alkalmazta, és folytatásra magyar földön nem talált. Az itt tárgyalt prágai nyomdászok viszont a bastarda mellett rotunda, textura, svabachi betüket használtak, és csak Jan Severinnel lépett fel az antikva, mint szövegbetű (1539-1540). Itt kell szólni a cseh nyomdászok viszonyáról az antikva típushoz, amely sarkalatos jelentőségü. A hagyományhoz való ragaszkodás a cseh nyel- vü irodalmi hagyományban a bastarda betüt jelentette, és idegenkedett a „pápista” antikvától. A bastardával való szakítás után az ennél sokkal könnyebben olvasható svabachi betűtípusra és a német fraktúrra tértek át, ez az 1540-es években következett be.

A környező országokban azonban a betűválasztás gyakorlata másképpen alakult. A Bécsben müködő kora reneszánsz mühelyek, Johann Singrieneré például nagy befolyással volt a lengyel könyvnyomtatásra, különösen amiatt, hogy német származású vagy Bécsben tanult nyomdászok telepedtek meg Krakkóban, de csekélyebb volt a hatásuk a cseh könyvnyomtatásra. Mindez azonban nem jelenti azt, hogy a cseh nyomdászok elszigetelten dolgoztak volna. Bizonyos nyomdai elemek nagyon korán meghonosodtak itt is, mint a fametszetü címerek alkalmazása vagy a kottanyomtatás. Az ezzel egyidejű magyarországi könyvnyomtatásról sajnos nem esik szó, pedig az 1540-es 1550-es években már a hazai reneszánsz könyv a virágkorát élte, mindenek előtt Heltai Gáspárnak és Joannes Honterusnak köszönhetően.

Amint az eddig elmondottakból is talán nyilvánvaló, Petr Voit kötete egyszerre rendkívül igényes bibliográfia, nyomdatörténet és tipográfiai repertórium. A cseh könyvnyomtatást a késő gótikától a kora reneszánszig tárgyaló szintézisnek első, most bemutatott kötetét remélhetőleg hamarosan követik a következő kötetek is: legközelebb különböző cseh nyomdahelyek és nyomdák bemutatására kerül sor, Nikolaus Bakaláŕtól Johann Güntherig (2017).

V. ECSEDY JUDIT

\section{Kovács Eszter, A Makula nélkül való tükör cseh forrásai, Budapest, MTA-PPKE Barokk Irodalom és Lelkiség Kutatócsoport, 2014, 156 p. (Pázmány Irodalmi Műhely Lelkiségtörténeti tanulmányok, 9)}

Az olvasó egy különleges forráskiadványt tart a kezében. A nagyszombati klarissza kolostor

* Az MTA - OSZK Res Libraria Hungariae Kutatócsoportban készült. 
falain belül a 18. század elején Krisztus szenvedéstörténetéről egy olyan mü született, amelyet még a 20. század első felében is gyakorta forgattak a katolikus hívők, okulásul pedig esténként nagyszülők az unokáknak olvastak föl belőle. Ez az említett könyv először 1712-ben Nagyszombatban jelent meg, s amint a címlapján olvasható, egy Makula nélkül való tükör, melly az üdvözitö Jesus Kristusnak, és szent Szüléinek életét, úgy keserves kinszenvedését, és halálát adgya elé. Melly Superiorok Engedelmébül Szüz, Szent Klára Szerzetében lévö Ujfalusi Judith által Cseh nyelvböl, Magyar nyelvre fordittatott. És a tekintetes és Nagysagos Ujfalui Ujfalusi Klára Aszszonynak, tekintetes, és nagysagos Karancs Berényi György Uram, ö Nagysága kedves Házás-társának költségén ki-bocsáttatott.

A Makula nélkül való tükör címlapja szerint nem önálló alkotásról van szó, hanem cseh nyelvből fordított müről. Ám szerzője, Újfalusi Judit nem árulja el, mi is, illetve mik is ezek a cseh nyelven írott források. Vida Tivadar korábban már részben megoldotta ezt a kérdést (Makula nélkül való tükör = Magyar Könyvszemle, (83)1967, 250-253). Kutatásai során bebizonyította, hogy szerzetes írónőnk a kor híres kegyességi szerzőjének, Martin von Cochemnek Jézus életéről szóló művét, a Das grosse Leben Christi 1698-ban készült cseh nyelvü változatát, a Veliký životot forgatta (Kochemu, Martin z: Veliký život Pána a Spasitele našeho Krista Ježíše a jeho nejsvětějši a nejmilejši matky Marie Panny. Praha, Argo, 2007. Kritikai szövegkiadás). A mü rendkívül elterjedt volt Európa-szerte. Újfalusi Judit számára a cseh nyelv szolgált közvetítő nyelvként. A klarissza apáca Divékújfalun, családjának ősi birtokán nevelkedett, ahol együtt éltek szlovákok és magyarok. Minden bizonnyal olvasási élményét, amint az ajánlásából kiderül, meg akarta osztani nővérével, de elsődleges célja mégiscsak az lehetett, hogy Cochem Jézus életrajzát magyar nyelven olvashassák klarissza rendtársai, a nyomtatás segítségével pedig kilépve a kolostor zárt falai közül, minél szélesebb rétegekhez is eljuthasson. Már Vida Tivadar is észrevette, hogy „nem egyszerü fordításról, hanem átdolgozásról van szó”. Mindezt megerősítették Kedves Csaba későbbi kutatásai (Magyar nyelvü drámatöredék a 15. század végéröl. In: A magyar színház születése. Az 1997. évi konferencia elöadásai, Szerk. Demeter Júlia, Miskolc, Miskolci Egyetem, 2000, 200-209). Ö ugyan a magyar dráma gyökereit kereste, ami közben az is föltünt neki, hogy a Makula nélkül való tükörben nagycsütörtökön ugyanazok a jelenetek olvashatók (égi pör és Krisztus fegyverei), amely két, korai nyelvemlékünkön, a 15-16. század fordulóján írott ún. Piry-hártyán, és a Máriabesnyői töredéken is. Szorosabb összefüggést nem feltételezett a középkori és az újkori szöveg között, arra gondolt, ugyanabból a forrásból táplálkozhattak. E sorok szerzőjének adatott meg, hogy bebizonyítsa, Újfalusi Judit a neves kapucinusnak, Cochemnek művét nem csak fordította, hanem ki is egészítette annak a nagyszombati zárdában őrzött kódexnek a szövegével, amely mára már elveszett, és csak három levél maradt belőle hírmondónak: a Piry-hártya levélpárja és a Máriabesnyői töredék (Egy középkori nyelvemlék 18. századi továbbélése, A Piry-hártya egykori kódexe és a Makula nélkül való tükör = Magyar Könyvszemle, (128)2012, 234-255).

Ezek után világossá vált, hogy Vida Tivadar kutatásait érdemes továbbfolytatni, a Veliký životot fejezetről fejezetre, sőt mondatról mondatra összevetni a Makula nélkül való tükörrel. A jó szerencse mellénk szegődött. Kovács Eszterrel, aki cseh szakot végzett a Pázmány Péter Tudományegyetemen, közös az asztaltársaságunk az Országos Széchényi Könyvtár ebédlőjében. E kis társaság az asztali beszélgetések során tudományos eredményeit is megosztja egymással, figyelemmel kíséri egymás munkáját. Egy, a Makula nélkül való tükör és a nyelvemlékek kapcsolatáról folytatott beszélgetés után Kovács Eszter komoly elszántsággal, és még nagyobb kitartással fogott hozzá, hogy elvégezze a Vida Tivadar által megkezdett munkát. Vagyis hogy bebizonyítsa, Újfalusi Judit nem csak fordította, hanem sok esetben alaposan átdolgozta, és hosszabb betoldásokkal ki is egészítette a Veliký životot.

Kovács Eszter így megszületett forráskiadványa két fő részre oszlik. Egy bevezető, fejezetekre osztott tanulmányrészre (7-92.) és 
magára a szöveggyüjteményre (93-153.). A bevezető tanulmány elöször röviden összefoglalja a Makula nélkül való tükörhöz kapcsolódó korábbi szakirodalmat (ezeket feljebb ismertettük), majd ír a mü keletkezéstörténetéröl. Kitér Martin von Cochem életrajzi adataira, a cseh fordító Edelbert Nymburskỳ személyére, munkamódszerére, és megoldást keres arra a kérdésre, hogyan is juthatott hozzá Újfalusi Judit a cseh változathoz, és annak melyik kiadását használta (7-11.). A tanulmány ezután rátér a Makula nélkül való tükör tartalmi egységeinek vizsgálatára. A magyar fordítás jóval kisebb terjedelmü az alapmünél. Ennek oka az, hogy Újfalusi Judit célja nem Cochem müvének fordítása volt, hanem csak eszközként használta, hogy a legszebb Krisztus-életrajzzal kedveskedhessen testvérének, Újfalusi Klárának és olvasóinak. Ezért a klarissza apáca Cochem első 27 fejezetét úgy ahogy van, el is hagyja. Ezek a részek az eredetiben rövid teológiai és történeti alapvetésként szolgáltak a későbbi fejezetekhez. A magyar változat ezzel szemben csak Szent Emerencia életével kezdődik, és valójában három nagy szerkezeti egységre tagolódik, követve az egyházi év ünnepköreit, de Cochemmel ellentétben nem az ünnepeken, hanem a magyar nyelvű változatban a történetiségen van a hangsúly.

Kovács Eszter tanulmányában - hogy áttekinthetőbbek legyenek kutatási eredményei a három szerkezeti egységet elemzéséhez különválasztja: 1. az ádventi és karácsonyi időszak, amely Jézus születésének előzményeit és gyermekségtörténetét mondja el; Szent Emerencia történetéig nyúlik vissza (1-51. fejezet); 2. a nagyböjti időszak, amely Jézus megkísértésétől a feltámadás előestéjéig tart (52-107. fejezet); 3. a húsvéti időszak, amely a feltámadásról szóló első hírektől Szüz Mária mennybevételéig kíséri nyomon Jézus életét (108-129. fejezet). Itt meg kell jegyeznünk, történt egy elírás: a könyv 66. oldalán kezdődő fejezet címébe a $M a-$ kula nélkül való tükör 129 . fejezete helyett tévesen a Veliký životnak az e fejezetnek megfelelö 168. fejezetszáma került, következésképp a tartalomjegyzékbe is). Kovács Eszter a három szerkezeti egységen belüli fejezeteknek először röviden ismerteti ismert és feltételezett forrásait. Ezután az egyes fejezetek összehasonlítása következik, ahol részletesen kifejti, milyen eltérések fedezhetök fel az alapszöveg (Veliký život) és a fordítás (Makula nélkül való tükör) között.

A szerző kutatásaiból kitünik, hogy az első szerkezeti egységben Újfalusi Judit kisebb eltérésektől eltekintve ragaszkodik az alapforráshoz, a Veliký živothoz, de azokat a részeket, melyek szervesen nem illeszkednek Jézus életrajzához, bátran kihagyja. Csak egyetlen helyre kerül betoldásként egy szép imádság, a 43. fejezet végére.

A második szerkezeti egység ennél jóval problematikusabb. A Veliký živothoz képest a kiegészítések itt jelentősen megszaporodnak. Szemmel láthatóan Krisztus kínszenvedésének története mélyen megérintette Újfalusi Juditot, és itt már nem elégedett meg a Cochemnél olvasottakkal. A nagyheti események szövegeinek összeállítása komoly szerkesztői munkára vall. Amit biztosan állíthatunk, hogy több, nagyszombati kolostorban örzött kódex passiótörténetéből is másolt be szívéhez igen közelálló jeleneteket, részleteket (a Piry-hártya és a Máriabesnyői töredék akkor még meglévő kódexe, Érsekújvári kódex). Ezeken a szövegeken kívül egyelöre még csak találgathatunk, hogy a többi betoldás honnan is került bele a Makula nélkül való tükörbe. Kovács Eszter fölveti, hogy a magyar nyelvemlékeken kívül akár egy másik cseh nyomtatványra is támaszkodhatott Újfalusi Judit, a Život Pánára, amely a korábban Bonaventura művének tartott Meditationes vitae Christire támaszkodva, azt kibővítve Jézus és Mária történetét elmélkedi végig (Žiwot Pána a Spasytele nasseho Gežjsse Krysta Též Přeblahoslawené Panny a Matky geho MARYE Podlé sepsánj S. Bonawentury wssem pobožnỳm Křstianům k spasytedlnému vwažowánj predstaweny ... w Praze, 1693). Két esetben szövegszerü egyezést is kimutat a Život Pána és a Makula nélkül való tükör között (52. fejezet záró bekezdése és az 57 . fejezetben a betániai megkenés története). A 60-64. fejezet ugyan tartalmilag közelebb áll a Život Pánához, mint Cochem Krisztus életrajzához, de egymásból eredeztetni őket nem lehet. Így Kovács Eszter 
arra a megállapításra jut, az ismeretlen forrás egy Pszeudo-Bonaventura alapján készült, a Život Pánához hasonló életrajz lehetett. Mivel a szenvedéstörténet megjelenítésében kimutathatóan magyar nyelvemlékszövegeket használt fel Újfalusi Judit, meg merem kockáztatni azt a feltevést, hogy Jézus és Mária találkozásának leírásában is mára már elveszett nyelvemlékszövegekkel állunk szemben.

A harmadik szerkezeti egységben újra sok a betoldás. Újfalusi Judit a Krisztus feltámadását követő események érzékletes leírásához sokkal több részletet idéz fel Nikodémus evangéliumából, mint azt Cochem tette. A kérdés csak az, milyen nyelvü forrást használhatott. Kovács Eszter részletes érveléssel támasztja alá, hogy Újfalusi Judit egy, nyomtatásban is rendelkezésére álló cseh nyelvű Nikodémus evangéliumot fordíthatott le anyanyelvére, s ezek közül is az 1651-es kiadás szövegével mutat leginkább rokonságot (Cžtenij Nykodemowo. W němž se wypisuje, co se dálo při vmučenj Krysta Pána... W Holomaucy, 1651). A kérdés végleges eldöntésére azonban a későbbiekben még alapos filológiai kutatásra lesz szükség.

A forráskiadvány a szöveggyüjteménnyel zárul. A Makula nélkül való tükörből kiemeli egyrészt azokat a részeket, amelyek Cochem Krisztusról szóló életrajzából hiányoznak, másrészt amelyek ugyan szoros kapcsolatban állnak az eredeti Cochem-szöveggel, de esetükben más forrásokra is támaszkodott Újfalusi Judit. Azokat a részeket, melyeket a Veliký životban, a Život Pánában, illetve a Čteni Nykodemovoban talált meg - vagyis a cseh forrásokat -, dőlt betükkel szedte, a magyar nyelvemlékeket vastagítással jelölte. A kiadvány végén egy személynévmutató és egy cseh nyelvű rezümé segíti a tájékozódást.

Kovács Eszter kutatásai újabb adalékokat szolgáltatnak ahhoz a sürü szellemi, lelki, kulturális hálónak a jobb megismeréséhez, amely Közép-Európa országait és népeit összekapcsolta. A Makula nélkül való tükör szinte egyformán gyökerezik a német, cseh és magyar hagyományban. A szerző azzal, hogy Újfalusi Judit Krisztus életrajzából kiemelte és közölte azokat a részeket, melyek nem Cochem Krisz- tus életrajzából valók, megteremtette a lehetőségét, hogy további részleteket azonosíthassanak a kutatók eddig ismert vagy újonnan felbukkanó forrásokban.

LAUF JUDIT

Ujfalusi Judith, Makula nélkül való tükör, melly az üdvözitö Jesus Kristusnak, és szent Szüléinek életét, úgy keserves kinszenvedését, és halálát adgya elé. Melly Superiorok Engedelmébül Szüz, Szent Klára Szerzetében lévö Ujfalusi Judith által Cseh nyelvböl, Magyar nyelvre fordittatott. És a tekintetes és Nagysagos Ujfalui Ujfalusi Klára Aszszonynak, tekintetes, és Nagysagos Karancs Berényi György Uram, ö Nagysága kedves Házás-társának költségén ki-bocsáttatott Nagyszombatban, A Jesus Társasága Académiája bötüivel, 1712-Esztendöben, Fakszimile kiadás Frauhammer Krisztina utószavával: A Makula nélkül való tükör magyarországi hatástörténete, Pytheas Könyvmanufaktúra - MTA-SZTE Vallási Kultúrakutató Csoport, é. n. 543 p.*

Az utóbbi évtizedben szakmai körökben nagyon sokat foglalkoztak a Makula nélkül való tükörrel. Irodalomtörténészek, iskoladrámával foglalkozó kutatók, néprajzosok, nyelvtörténészek körében valóságos reneszánszát éli. 2014-ben még egy konferenciát is tartottak róla (Makulátlan tükör, Könyvbemutató és Mühelykonferencia a Makula nélkül való tükör címü kegyességi müröl, 2014. december 4, MTA-PPKE Barokk Irodalom és Lelkiség Kutatócsoport. A konferencián elhangzott előadások írott változatai megjelenés alatt). Ezeknek a kutatásoknak eredményeként nagyon sok új ismeretanyag halmozódott fel, s ezzel együtt a Makula nélkül való tükörnek az irodalmi kánonban betöltött szerepe is felértékelödött, és igény támadt egy hasonmás kiadásra is. Megjelentetését Frauhammer Krisztinának, a Szegedi Vallási Kultúrakutató Csoport tagjának köszönhetjük. A kísérő tanulmányt is ő jegyzi. A rendkívül jól felépí-

* Az MTA - OSZK Res Libraria Hungariae Kutatócsoportban készült. 